\title{
Climatic controls on frost cracking and implications for the evolution of bedrock landscapes
}

\author{
T. C. Hales ${ }^{1}$ and Joshua J. Roering ${ }^{1}$ \\ Received 26 June 2006; revised 7 November 2006; accepted 25 January 2007; published 14 June 2007.
}

[1] In mountainous landscapes the role of periglacial processes in producing sediment is poorly defined, despite evidence of abundant talus slopes. Ice growth in rock has long been recognized as an efficient erosion mechanism, but the effects have not been readily applied to landscape evolution in response to tectonic and climatic forcing. Here, we quantify how and where ice-driven mechanical erosion occurs in cold, bedrock-dominated landscapes using a simple one-dimensional numerical heat flow model. In our model, ice grows by water migration to colder regions in shallow rock by the reduction in chemical potential associated with intermolecular forces between ice and mineral surfaces, a process called segregation ice growth. The depth and intensity of frost cracking is primarily dependent on mean annual temperature (MAT), with positive MAT sites characterized by intense cracking in the top meter of the rock mass and a maximum frost penetration of $\sim 4 \mathrm{~m}$. In contrast, negative MAT areas have less intense cracking that primarily occurs at depths between 50 and $800 \mathrm{~cm}$. We compare the depth and intensity of frost cracking predicted by our model with measures of the intensity of frost processes determined in three studies: The first measured the timing of rockfall in the Canadian Rockies, Niagara Escarpment, and Japanese Alps; the second analyzed scree deposits in the Southern Alps, New Zealand; and the third documented rockfall frequency in Utah. These natural examples show that rockfalls tend to nucleate at elevations that coincide with zones of intense frost cracking predicted by our model. As such, climatic variations associated with interglacial-glacial cycles may impart a significant influence on the denudation of mountainous landscapes.

Citation: Hales, T. C., and J. J. Roering (2007), Climatic controls on frost cracking and implications for the evolution of bedrock landscapes, J. Geophys. Res., 112, F02033, doi:10.1029/2006JF000616.

\section{Introduction}

[2] Sediment production in mountainous regions reflects a complicated feedback between uplift, caused by rock uplift and isostatic rebound, and erosion, which includes the effects of glacial, periglacial, fluvial, and hillslope erosion. Uplift rates change over million-year timescales due predominantly to changes in plate motion and are manifest by broad changes in the sedimentary environment [DeCelles and DeCelles, 2001]. In contrast, climate change acts over a much shorter timescale and causes rapid pulses of sediment delivery to a basin, reflected by changes in facies, sedimentation rate, and terrace formation [Pan et al., 2003; Zhang et al., 2001]. In high mountains, these changes in sediment delivery have been directly related to the extent of glaciers, which are thought to be the most efficient erosional and transport mechanism in mountains [Brozovic et al., 1997; Hallet et al., 1996; Montgomery, 2002]. Recently, others have suggested that periglacial processes

\footnotetext{
${ }^{1}$ Department of Geological Sciences, University of Oregon, Eugene, Oregon, USA.

Copyright 2007 by the American Geophysical Union. 0148-0227/07/2006JF000616\$09.00
}

play an important role in erosion, such that glaciers and rivers serve to transport material out of the system [Pan et al., 2003; Zhang et al., 2001]. Quantification of the mechanisms and rates of periglacial erosion is of primary importance to understanding this question.

[3] The important role that periglacial processes play in mountain erosion is shown by the preponderance of sediment deposited as scree slopes on the flanks of glacial valleys (Figure 1). Enhanced periglacial erosion related to climate cooling events has been suggested as the mechanism causing rapid terrace accumulation events and rapid filling of sedimentary basins [Bull and Knuepfer, 1987; Pan et al., 2003; Zhang et al., 2001]. Zhang et al. [2001] noted that sediment yields in both offshore and internally drained basins across the globe show an increase in sedimentation rate at approximately 2-4 Ma, coincident with a change from a relatively stable climate to one with large oscillations on Milankovitch timescales. The authors proposed that periglacial processes fracture rock and prepare it for transport via glaciers. Similarly, Bull and Knuepfer [1987] suggested that terrace aggradation events are associated with cooler climates in which periglacial processes are most efficient (the study was undertaken in an unglaciated catchment). These studies highlight the need for a pro- 


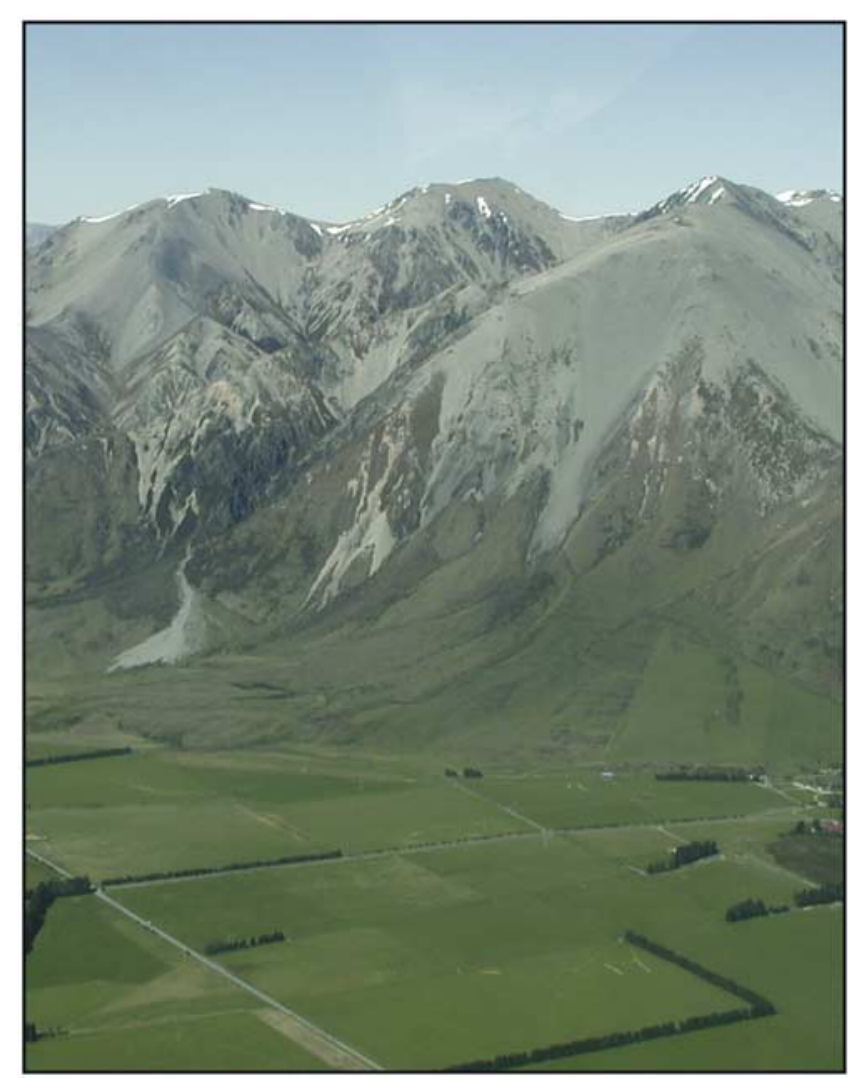

Figure 1. Oblique aerial photograph of large scree slopes caused by frost-driven bedrock erosion, Cragieburn Range, Southern Alps, New Zealand.

cess-based understanding of how frost action affects sediment production via the frequency and magnitude of rockfall generation.

[4] Ice-driven mechanical weathering has long been recognized as a causal factor in rockfall erosion. However, previous studies based on a limited number of localized headwalls or scree slopes have focused on the competing importance of ice processes and glacial or topographic unloading [Augustinus, 1995; Hinchliffe and Ballantyne, 1999], rock properties [Andre, 1997], and earthquakes [Matsuoka and Sakai, 1999]. These studies cover a wide range of climatic and tectonic settings including the European Alps [Sass and Wollny, 2001], the Scottish Highlands [Ballantyne and Eckford, 1984; Hinchliffe and Ballantyne, 1999], the Japanese Alps [Matsuoka and Sakai, 1999], Scandinavia [Andre, 1997; Rapp, 1960], the Canadian Rocky Mountains [Church et al., 1979; Gray, 1973], and Greenland [Frich and Brandt, 1985].

[5] The following examples highlight the diverse character of hypotheses regarding erosion via frost-induced rockfall. The timing of rockfall events and the amount of material accumulated on snow-covered scree slopes was measured by Matsuoka and Sakai [1999], who suggested that the intensity and duration of freezing and thawing cycles, combined with less frequent, large magnitude earthquake and precipitation events were the primary controls on rockfall of headwalls in the Japanese Alps. In Svalbard, Norway, a lichenometric study of rock walls of different rock types suggested that lithology was the primary control on rockfall erosion [Andre, 1997]. Beneath basalt cliffs, according to cosmogenic radionuclide dating of ${ }^{36} \mathrm{Cl}$ in olivine, $80 \%$ of rock wall retreat occurred within 6000 years of deglaciation. This pattern was interpreted as reflecting stress release following deglaciation combined with periglacial processes [Hinchliffe and Ballantyne, 1999]. Measurements of daily crack width changes on a rock wall in the Japanese Alps suggest that ice growth caused an increase in crack width during thawing periods [Matsuoka, 2001]. A study of the Southern Alps, New Zealand, showed that scree slopes occupy a relatively small elevation range that coincides with areas in which ice growth may be an important weathering mechanism [Hales and Roering, 2005]. Recent work modeling the depth to permafrost in the European Alps, suggested that the thaw of alpine permafrost during a particularly hot summer was responsible for enhanced rockfall erosion rates [Gruber et al., 2004]. Although these studies highlight a diverse data set of potential mechanisms and have shown that rockfall erosion can occur at geomorphically significant rates (headwall retreat rates of up to $49 \mathrm{~mm} / \mathrm{yr}$ [Zhu, 1996]), spatial and temporal controls on ice-driven bedrock erosion remains elusive.

[6] Recognition of the important role that ice plays in fracturing and liberating rock from headwalls has led to a number of theoretical and physical experiments that attempt to model ice lens growth [Hallet et al., 1991; Murton et al., 2001; Walder and Hallet, 1985]. These studies have addressed the mechanics of ice growth, particularly the role of premelted films in lens growth [Dash et al., 2006] and fracturing frequency of rocks under steady temperature gradients [Hallet et al., 1991; Murton et al., 2001]. However, the detail at which these studies have been undertaken makes it difficult to relate the physics of ice growth to rockfall erosion at geomorphic scales. Here, we provide a theoretical roadmap for predicting the spatial and temporal pattern of rockfall erosion on the basis of changes in climate and rock fracture spacing.

\section{Mechanisms for Rock Fracture by Ice Growth}

[7] The physics of ice/rock interactions are a source of debate amongst periglacial geomorphologists, with two competing hypotheses. The first suggests that the $\sim 9 \%$ volumetric expansion of ice formed in pore spaces increases tensional stress at crack tips and causes rock to break (hereafter called freeze/thaw). Subsequent thawing liberates the freshly fractured rock, causing rockfall. Freeze/thaw weathering has wide acceptance in the literature [e.g., Church et al., 1979; Coutard and Francou, 1989; Matsuoka and Sakai, 1999], but its applicability to natural systems has been questioned over the past 25 years [Murton, 1996; Walder and Hallet, 1985].

[8] In the 1980s, theoretical [Walder and Hallet, 1985] and experimental [Hallet et al., 1991] studies expanded upon an extensive soil mechanics literature [e.g., Gilpin, 1980; Taber, 1929] to suggest an alternative mechanism called segregation ice growth. They argued that for freeze/ thaw to break rock, at least $91 \%$ saturation in a "closed system" is required to create enough force from ice expansion to break rocks [Hallet et al., 1991]. In unsaturated or 
open systems, ice can expand to fill pore space without putting significant pressure on the pore walls. They argued that there are relatively few natural instances in which a completely closed or saturated system exists. Their alternative is a mechanism that can be applied more readily to natural systems involving the migration of water through a frozen fringe toward an ice lens where it accretes (hereafter called segregation ice growth) [Walder and Hallet, 1985]. The segregation ice mechanism proposes that the stress required to fracture rock (or heave soils) is provided by van der Waals and electrostatic forces (called disjoining forces) created at the ice/rock interface [Wettlaufer and Worster, 1995; Wilen and Dash, 1995]. These interfacial forces provide enough stress on fracture walls to cause a small amount of fracture at the crack tip. Once a rock has fractured initially, liquid water is drawn from warmer parts of the rock toward the site of failure along a chemical potential gradient [Wilen and Dash, 1995]. Liquid water exists at subfreezing temperatures at the interface between rock (or any other solid) and ice due to interfacial melting and curvature effects [Worster and Wettlaufer, 1999]. These nanometer-scale interfacial water layers (termed premelted films; see Wettlaufer and Worster [1995]) vary in thickness as a function of temperature, such that they are thinner at cooler temperatures. This thickness variation results in a difference in fluid pressure, which draws water toward the ice lens. These thin, premelted films provide interconnected pathways that allow water to migrate within the frozen zone where it can accrete to an ice lens [Rempel et al., 2004].

[9] The segregation ice mechanism requires that the forces acting at the rock/ice interface (called disjoining forces) are large enough to fracture rocks (or heave soil particles) and that interconnected interfacial water layers allow water to move within the frozen zone. The result is that the efficacy of this mechanism is limited to a small range of temperatures and depths within a rock (or soil column). At temperatures close to $0^{\circ} \mathrm{C}$, the disjoining forces are relatively weak although water is readily available because the interfacial layers are thick. By contrast, at temperatures well below $0^{\circ} \mathrm{C}$ (experimental evidence suggests $<-8^{\circ} \mathrm{C}$; see Hallet et al. [1991]), disjoining forces are strong, but viscous resistance severely limits flow in thin interfacial layers. In addition, disjoining forces must be strong enough to overcome overburden stresses and cohesive strength of the rock or soil.

[10] In soils, segregation ice growth is largely accepted as the dominant cause of frost heave, due to an extensive history of theoretical and physical experimentation [Gilpin, 1980; Henry, 2000; O'Neill and Miller, 1985; Rempel et al., 2004; Taber, 1929]. Ice lenses have grown in porous materials containing a wide range of liquids including water, benzene [Taber, 1929], helium [Hiroi et al., 1989] and argon [Zhu et al., 2000], some of which contract upon freezing. A similar mechanism may occur in rock masses [Walder and Hallet, 1985], except that forces occurring at the rock-ice interface must overcome the cohesive strength of the rock mass in order for lens growth to occur. While considerably less theoretical and physical experimentation has occurred on rocks than soils, experiments measuring the location of cracking events [Hallet et al., 1991] and the amount of rock mass heave [Murton et al., 2001] suggest that the segregation ice mechanism may be responsible for a significant amount of fracturing in rock masses. This is further supported by field experiments measuring the change in crack width with time in the Japanese Alps, which showed that the peak crack width coincided with a peak in water availability in the spring [Matsuoka, 2001].

[11] For geomorphologists, the most important difference between the segregation ice growth and freeze/thaw mechanisms is the temperature conditions over which they operate. Freeze/thaw weathering requires temperature oscillations about $0^{\circ} \mathrm{C}$, whereas segregation ice grows at a temperature range that maximizes the availability of water and the strength of the disjoining forces needed to crack rock. Theoretical and experimental work suggests that the growth of segregation ice lenses depends primarily on absolute temperature (the growth rate is largest at -3 to $-8^{\circ} \mathrm{C}$ ), the amount of available water, and a temperature gradient that allows water to be drawn from warmer $\left(>0^{\circ} \mathrm{C}\right)$ to cooler regions of the rock [Hallet et al., 1991; Matsuoka, 2001; Murton et al., 2001; Taber, 1929; Walder and Hallet, 1985; Wilen and Dash, 1995; Zhu et al., 2000]. These differences between hypothesized mechanisms are critical for understanding mountain evolution, particularly the elevation at which sediment is likely to be produced and the temperature conditions associated with rock mass failure. If freeze/thaw is the dominant mechanism, maximum frost cracking intensity (and rockfall erosion) should occur at an elevation that experiences the greatest number of oscillations across $0^{\circ} \mathrm{C}$. If the segregation ice growth mechanism dominates, the maximum frost cracking intensity should occur at an elevation that spends the most amount of time within a temperature range of approximately -3 to $-8^{\circ} \mathrm{C}$ (in the presence of available water).

[12] To explore the role of segregation ice growth on mountain evolution we present a simple one-dimensional heat flow model that describes how the intensity of segregation ice growth varies with depth. Our model extends the work of Anderson [1998] who used an analytical solution to understand the number of days a rock spends within a temperature controlled window (which he termed the frost cracking window). We have extended his work to account for hydrologic and temperature gradient factors. Our model is based on an analytical solution for heat flow in a solid mass with a sinusoidal, annually varying upper boundary condition (derivation of this solution is described by Carslaw and Jaeger [1959]; application to permafrost systems is described by Gold and Lachenbruch [1983]).

\section{Model Setup}

[13] We modeled shallow bedrock heat flow in an attempt to predict the depth at which segregation ice is likely to form in a rock wall. Conduction is the primary method of heat transfer in rocks at Earth's surface [Turcotte and Schubert, 2002]. Neither radiative or convective cooling are thought to play major roles in heat transfer within solid rock, but rocks with large interconnected pore spaces filled with fluid may experience a component of convective cooling [Harris and Pederson, 1998]. In the case of highly fractured rock the relative roles of conduction and convection have not been assessed, but we assume that conduction dominates [Anderson, 1998; Gold and Lachenbruch, 1983]. 
The analytical solution for one-dimensional heat conduction given a sinusoidal surface temperature variation is

$$
\mathrm{T}(z, t)=M A T+T a e^{-z \sqrt{\frac{\pi}{\alpha P_{y}}}} \sin \left(\frac{2 \pi t}{P_{y}}-z \sqrt{\frac{\pi}{\alpha P_{y}}}\right),
$$

where $\mathrm{T}$ is temperature, $\mathrm{t}$ is time, $\mathrm{z}$ is depth in the rock, MAT is the mean annual temperature, Ta is the half amplitude of the sinusoidal variation, $\mathrm{P}_{\mathrm{y}}$ is the period of the sinusoid (our model uses an annual cycle) and $\alpha$ is the thermal diffusivity (between $1-2 \mathrm{~mm}^{2} \mathrm{~s}^{-1}$ for most rocks) [Anderson, 1998; Carslaw and Jaeger, 1959; Gold and Lachenbruch, 1983]. This model predicts that the daily temperature cycle is attenuated by an order of magnitude at $35 \mathrm{~cm}$ and the annual temperature cycle is comparably attenuated to a depth of $700 \mathrm{~cm}$ [Gold and Lachenbruch, 1983].

[14] We calculated the location and efficacy of segregation ice growth using three criteria. The first is that the rock temperature at which segregation ice grows is between -3 and $-8^{\circ} \mathrm{C}$ [Hallet et al., 1991]. Second, water $\left(\mathrm{T}>0^{\circ} \mathrm{C}\right)$ is available to the system, which corresponds to scenarios with melting conditions at the surface, or unfrozen groundwater at depth. In our model, water is available when either boundary has a temperature above $0^{\circ} \mathrm{C}$. Finally, when water is available to the system from groundwater (defined as when the lower boundary at $20 \mathrm{~m}$ depth is above $0^{\circ} \mathrm{C}$ ), segregation ice grows when the temperature gradient is positive (i.e., water is drawn from warm to cold). Alternatively, when water is available at the upper boundary (during times of melting), segregation ice grows when the temperature gradient is negative.

[15] In an attempt to directly relate our model to frost cracking processes we use the temperature gradient as a proxy for frost cracking intensity. Ice segregation theory suggests that the growth rate of segregation ice varies with the temperature gradient [Worster and Wettlaufer, 1999]. A steeper temperature gradient reflects a steeper gradient in chemical potential and therefore more rapid delivery of water to sites of ice accretion. The rate of ice lens growth is primarily dependent on water availability [Wettlaufer and Worster, 1995], so more efficient delivery of water to the system will result in faster lens growth, greater stress at crack tips, and more intense frost cracking at that location. We suggest therefore that by summing the temperature gradient at every predicted location over the course of an annual cycle we can quantify the rate of segregation ice growth. Because of a strong predicted relationship between the growth rate of ice and frost cracking intensity [Walder and Hallet, 1985], we have used the annual sum of the temperature gradient as a function of depth as a proxy for the intensity of frost cracking.

[16] We solved equation (1) at daily intervals for a year with Ta varying between 4 and $20^{\circ} \mathrm{C}$ and MAT varying between -5 and $5^{\circ} \mathrm{C}$, reflecting the variation in MAT and variability of mountainous and arctic areas around the world [Anderson, 1998]. At depths below the penetration of the maximum annual cycle, we kept the rock mass at a constant temperature consistent with the mean annual temperature. Because the maximum depth of frost penetration was $\sim 14 \mathrm{~m}$, the effects of geothermal heating are negligible (a typical geothermal gradient is $\sim 0.025^{\circ} \mathrm{C} / \mathrm{m}$; see Turcotte and Schubert [2002]) when compared with surface temperature changes.

\section{Model Assumptions}

[17] We attempted to model the complicated physics of segregation ice growth using readily accessible parameters, such that several assumptions are embedded in our calculations. The first is that the segregation ice mechanism is most effective in rock at temperatures between -3 and $-8^{\circ} \mathrm{C}$. As we have discussed above, the efficacy of segregation ice growth is also highly dependent on the cohesive strength of the rock mass and the overburden pressure at the location of ice growth.

[18] The second important assumption regards the availability of water in our model system. Water is available at the surface in the spring during thawing periods or from a groundwater system that is above $0^{\circ} \mathrm{C}$. In the spring, one often observes considerable water along the surface. These observations are supported by direct measurement of crack widening in the spring thaw in the Japanese Alps [Matsuoka, 2001]. The presence of groundwater in steep alpine cliffs is more difficult to justify as few measurements have been made because of the difficulty of instrumenting these areas. A recent study used a number of geophysical techniques to show that the moisture content of rocks in the European Alps varied considerably, from 50 to $100 \%$ at $5 \mathrm{~cm}$ depth to a nearly uniform $80 \%$ at $10 \mathrm{~cm}$ depth [Sass, 2005]. The results of this study suggest that groundwater is present in alpine cliffs and thus may be available to promote segregation ice growth, although the rate of water movement is dependent on the permeability of the interconnected pores and the magnitude of the chemical potential gradient.

[19] Our model focuses on the annual temperature cycle and neglects diurnal effects. The diurnal variation is important only in the top few centimeters of the rock mass, as it is attenuated by an order of magnitude at a depth of $35 \mathrm{~cm}$. Although this may be an important component in some areas, the effects of diurnal variations are relatively small compared with those of the annual cycle. The assumption of a sinusoidal annual temperature variation provides the simplest reasonable approximation of a natural system. In detail, the annual cycle approximates a sinusoid during cooling periods (autumn), but natural temperature rise much more slowly during warming periods (spring). Air temperature close to Earth's surface is primarily dependent on the sun's energy reradiated from the ground [Linacre and Geerts, 1997], so slow warming of Earth's surface in the springtime causes this anomaly. However, the effect of this small discrepancy within our model is relatively minor.

[20] We assume that atmospheric temperature is representative of rock surface temperature. The relationship between rock temperature and atmospheric temperature is affected by rock type, albedo and aspect [Hall et al., 2005]. Rocks that have a low albedo and/or are exposed to long periods of solar radiation typically reach temperatures significantly higher than atmospheric temperature for seconds to minutes [Anderson, 1998]. This can result in a discrepancy between atmospheric MAT and a MAT measured at the rock surface of up to $8^{\circ} \mathrm{C}$ [Coutard and Francou, 1989]. However, the surface temperature of fully 


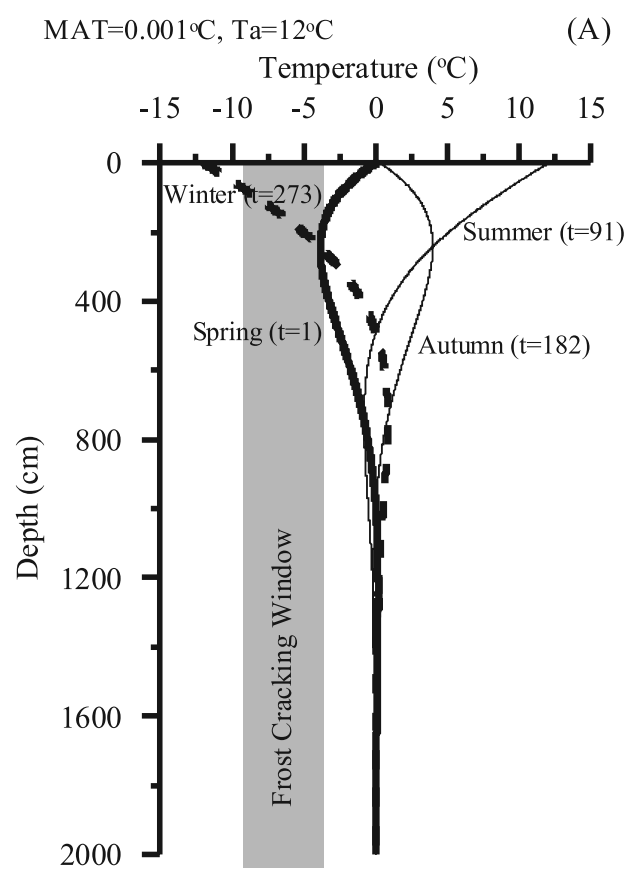

(B)

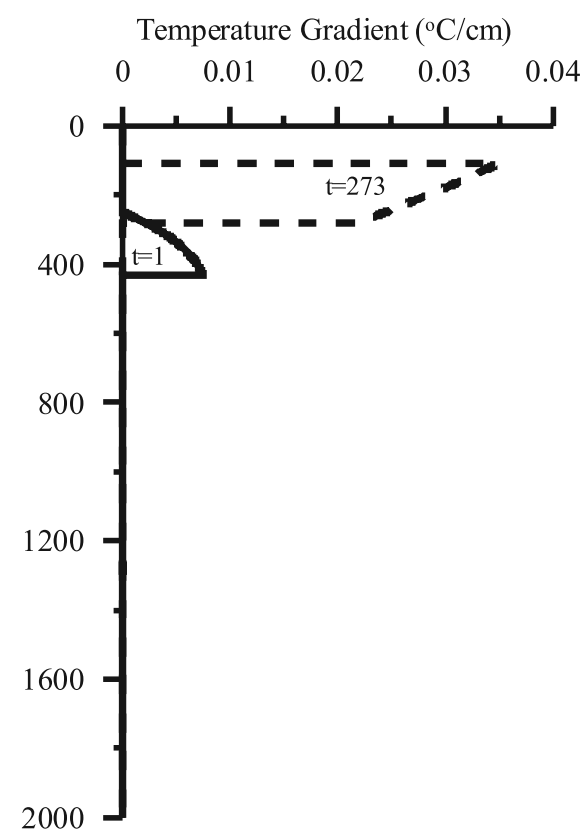

Figure 2. Results for our heat flow model using a MAT of $0.001^{\circ} \mathrm{C}$ and an annual temperature variation (Ta) of $12^{\circ} \mathrm{C}$. (a) Some representative temperature profiles at time steps 1 (spring), 91 (summer), 182 (autumn), and 273 (winter). Highlighted in solid black (day 1) and dashed lines (day 273) are examples of when our model will predict segregation ice to grow. The intensity of ice growth is primarily a function of temperature gradient, and its daily values are shown in (b).

shaded rocks is similar to measured atmospheric temperatures [Matsuoka and Sakai, 1999]. Our simple model does not attempt to capture all of the variability in rock temperature, but uses atmospheric temperature as a proxy for the shade temperature of rock.

[21] This model seeks to understand potential locations of segregation ice growth and does not consider the saturation, permeability or porosity of the rock. We assume that water can move readily, and is limited only by temperature effects. Segregation ice growth in rocks will, in reality, be limited by differences in rock properties, particularly cohesive strength, fracture spacing, and thermal properties. Of these properties, fracture spacing is possibly the most important control on porosity, permeability and cohesive strength of rocks [Selby, 1993]. These assumptions are necessary for the simplification of our model and suggest that our predictions represent maximum values for the depth and cracking intensity of rock masses.

\section{Model Results}

[22] We determined the depth, timing and intensity of segregation ice growth for a range of MAT and annual temperature variations ( $\mathrm{Ta})$ that represent temperature conditions commonly observed in nature. MAT primarily controls the availability of water while Ta controls the depth of segregation ice growth and cracking intensity.

\subsection{Timing of Segregation Ice Growth}

[23] The timing of segregation ice growth reflects the interaction between the mean rock temperature and the temperature of the upper boundary condition (i.e., time of the year). During the autumn and early winter, the surface temperature gets cooler, creating a positive temperature gradient close to the surface that draws water from the warmer interior of the rock toward the surface (e.g., Figure 2a, time step 273). This suggests that the segregation ice growth is likely to occur only in rock masses that have available groundwater (i.e., positive MATs). In the late winter and spring, the surface warms such that the temperature-depth profile has a negative temperature gradient close to the surface that allows water to be drawn from the surface, suggesting segregation ice growth for negative MATs (e.g., Figure 3a, time step 1).

[24] For regions with positive MAT, segregation ice grows in the autumn, winter and spring. In this case the lower boundary condition (the internal part of the rock) is always above $0^{\circ} \mathrm{C}$, such that water is available from the groundwater system in the warmer interior of the rock. Thus the number of days during which segregation ice grows is a function of the number of days with a positive temperature gradient at depths where the temperature is between -3 and $-8^{\circ} \mathrm{C}$ (hereafter called the frost cracking window) (Figure 2). In the autumn and early winter (between days 182 and 273 in Figure 2) the temperature at the surface decreases rapidly, creating large positive temperature gradients close to the surface. These steep temperature gradients cause rapid segregation ice growth during the autumn (Figure 2, time step 273). In the late winter and spring, the surface temperature increases, causing negative temperature gradients at the surface and stopping nearby ice growth. However, there is a lag between temperature at the surface and interior depths, resulting in deep ice growth in the spring (Figure 2, time step 1). 

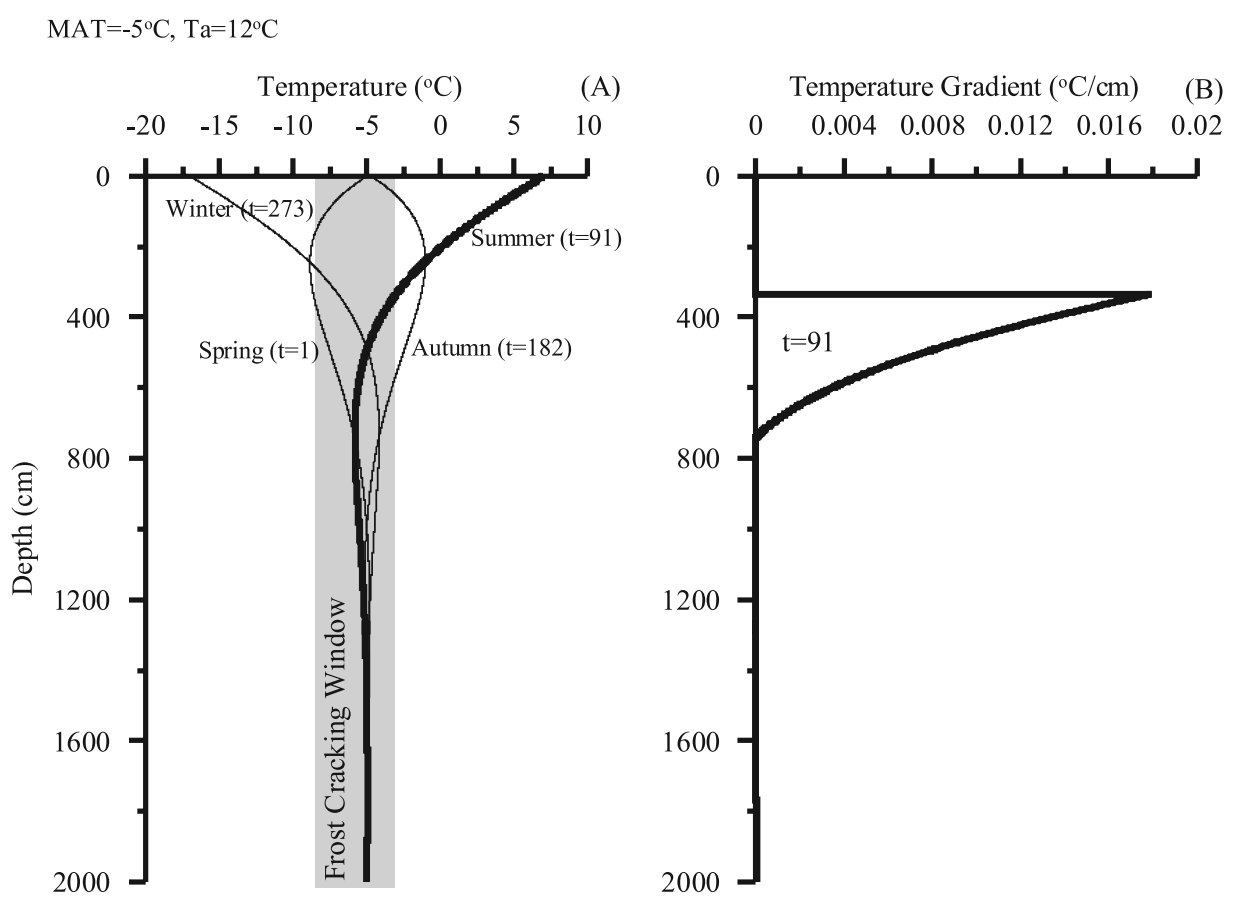

Figure 3. Results for our heat flow model using a MAT of $-5^{\circ} \mathrm{C}$ and an annual temperature variation of $12^{\circ} \mathrm{C}$. (a) Representative temperature profiles at time steps $1,91,182$, and 273 . Highlighted in solid black (day 91) is an example of when our model will predict segregation ice to grow. The intensity of ice growth is primarily a function of temperature gradient, and its daily values are shown in (b).

[25] Segregation ice growth is limited for negative MAT areas because water is only available to the system when the surface temperature is above zero (Figure 3a, time step 91). In this case, segregation ice grows in an active layer, where water is available from snow melt and follows a negative temperature gradient. The contribution of snowmelt and the formation of an active layer only occur in the spring and summer months.

\subsection{Influence of Mean Annual Temperature}

[26] Mean annual temperature affects the overall behavior of this system by controlling the availability of water (Figure 4). Changes in MAT cause both the depth of ice growth and the depth of maximum cracking intensity to deepen. For positive MAT sites, the maximum depth of segregation ice growth and maximum cracking intensity gets deeper with decreasing MAT. For example, at a MAT of $5^{\circ} \mathrm{C}$ the maximum depth of ice growth is $120 \mathrm{~cm}$, with the maximum cracking intensity located at the surface, whereas for MAT equal to $0.001^{\circ} \mathrm{C}$ (representing a minimum positive MAT, at $0^{\circ} \mathrm{C}$ water is not available from groundwater) the maximum ice growth depth is $430 \mathrm{~cm}$ and the depth of maximum cracking intensity is $150 \mathrm{~cm}$. The difference in the depth of maximum cracking intensity between MAT of 0.001 and $5^{\circ} \mathrm{C}$ reflects the proportion of the year our model predicts cracking to occur (Figure 5). At $0.001{ }^{\circ} \mathrm{C}$, the surface temperature varies between -12 and $12^{\circ} \mathrm{C}$ (as compared with -7 and $17^{\circ} \mathrm{C}$ for a MAT of $5^{\circ} \mathrm{C}$ ) and diffusion of heat from the surface allows deeper rock to enter the frost cracking window. The overall shape of the frost cracking curve (Figure 4) somewhat resembles profiles of the number of days spent within the frost cracking window (Figure 5). The difference arises from the influence of the temperature gradient, which is steepest close to the surface such that predicted cracking intensity is higher close to the surface than at depth. For higher MATs, which barely penetrate the -3 to $-8^{\circ} \mathrm{C}$ temperature window (e.g., 4 and $5^{\circ} \mathrm{C}$ ) the maximum cracking intensity is close to the surface. When the surface temperature cools below $-8^{\circ} \mathrm{C}$, the depth of maximum cracking intensity moves away from the rock surface and decreases in peak intensity.

[27] Negative MATs show a much more complicated response to changes in MAT because water is only available for limited periods during the year. The cracking intensity curves show (1) a broad peak centered between 200 and $300 \mathrm{~cm}$, (2) negligible cracking within $80 \mathrm{~cm}$ of the surface, and (3) a long tail that extends deeper than $1000 \mathrm{~cm}$ (Figure 4b). Also, the peak cracking intensity is an order of magnitude less than for positive MAT sites. The depth pattern of cracking intensity for MAT just below zero reflects the number of days available for segregation ice growth (c.f. Figures $4 b$ and $5 b$ ). For lower temperatures (between -3 and $-5^{\circ} \mathrm{C}$ ) there are two distinct inflections in the cracking intensity distribution (Figure 4b). The upper broad peak corresponds to the depth with the steepest average temperature gradient and reflects the relatively large number of ice growth days. A second inflection point occurs at depths below $500 \mathrm{~cm}$, reflecting a rapid decrease in the number of days at which cracking occurs (because of relatively short periods of time spent with a negative temperature gradient).

[28] An important feature of these simulations is the sharp transition in behavior between $0.001{ }^{\circ} \mathrm{C}$ and $0^{\circ} \mathrm{C}$. This transition is a result of the assumption that water is available from the groundwater system at MATs above $0^{\circ} \mathrm{C}$. In our model, this transition represents the change from a seasonal 


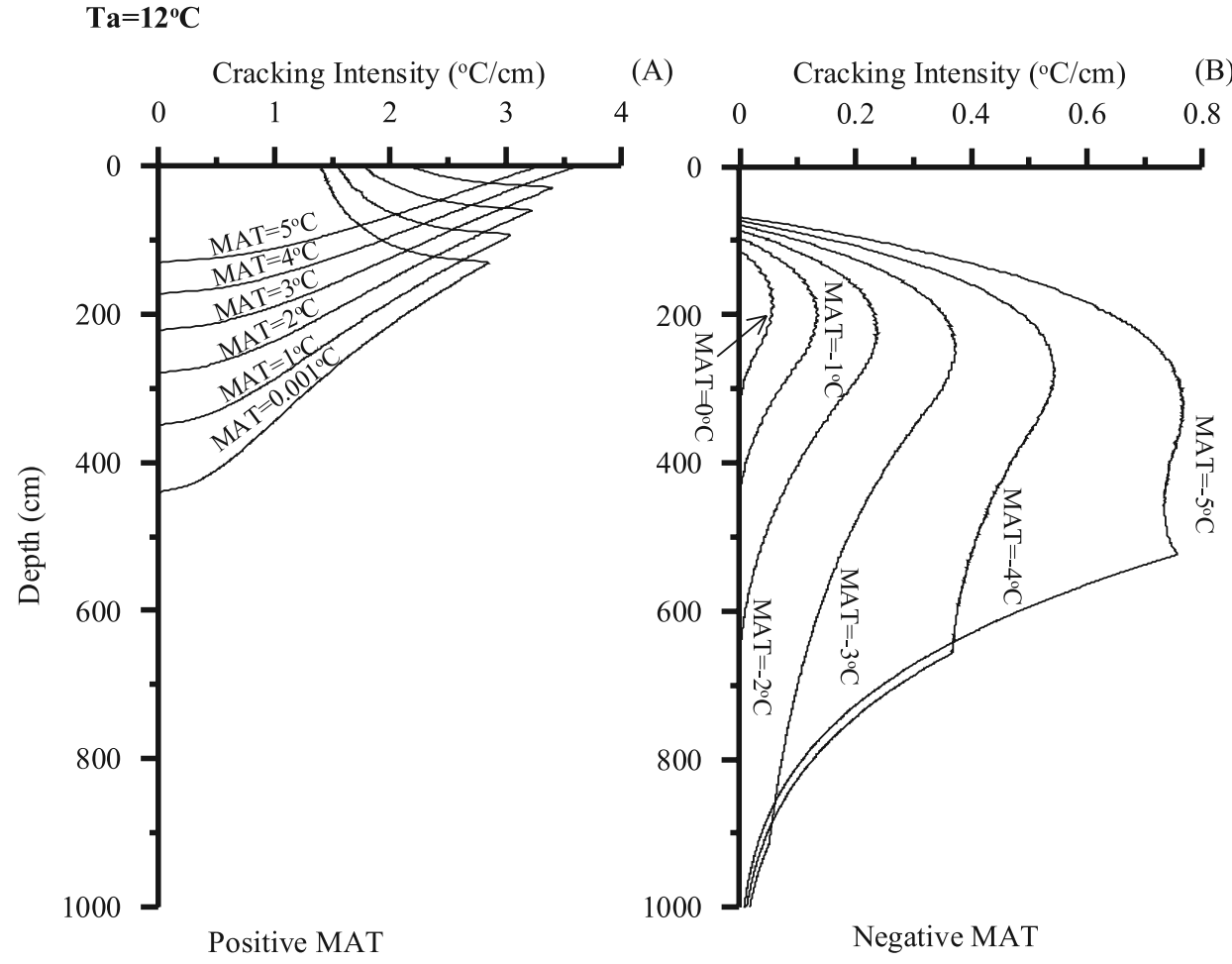

Figure 4. Changes in cracking intensity as a function of MAT for Ta of $12^{\circ} \mathrm{C}$. (a) Variations in the cracking intensity and depth of segregation ice growth for positive MATs. (b) As in Figure 4a for negative MATs.

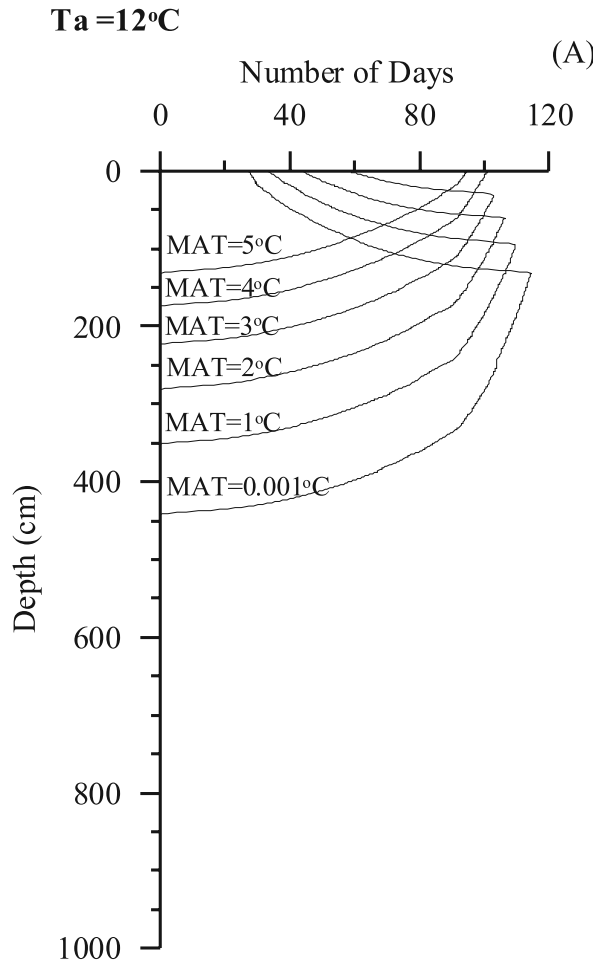

Positive MAT
(A)

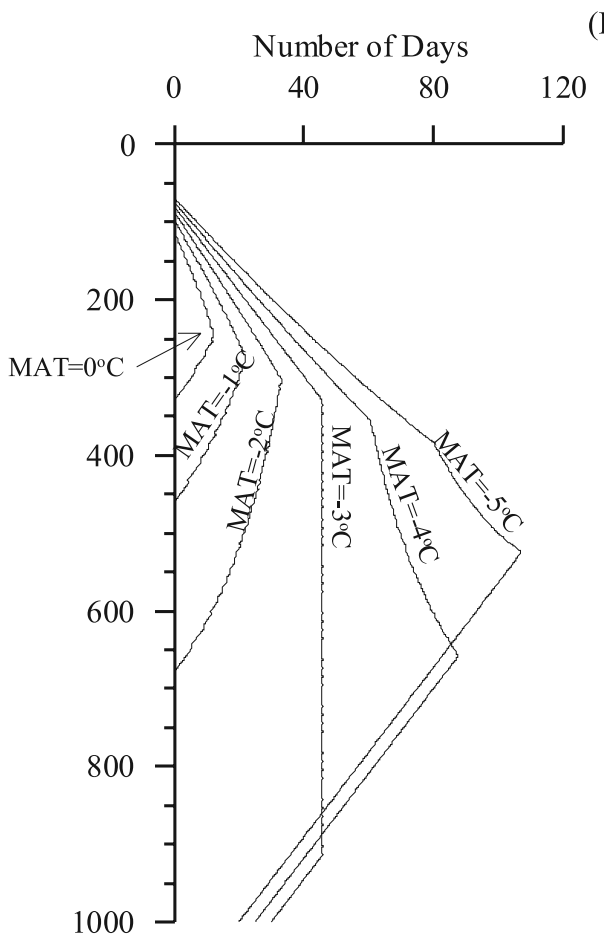

Negative MAT

Figure 5. The number of days spent in the frost cracking window as a function of depth for (a) positive and (b) negative MAT. The data in Figure 5a show the predicted frost cracking window estimated by Anderson [1998] (recalculated from his paper). 

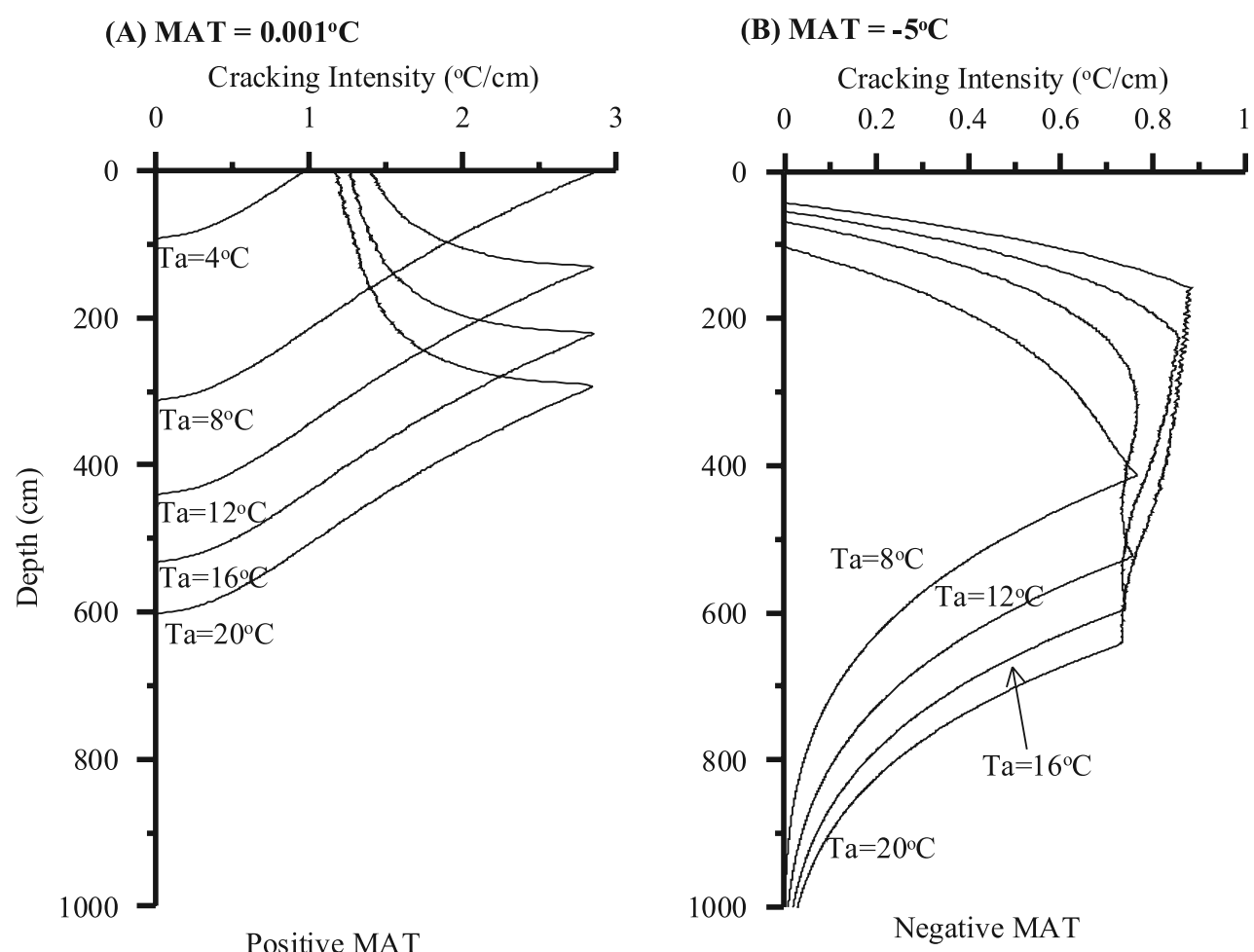

Figure 6. Changes in cracking intensity with depth for different Ta and a MAT of (a) 0.001 and (b) $-5^{\circ} \mathrm{C}$.

ice condition to one of permanent ice (permafrost). While the abruptness of this change may be difficult to justify in natural systems, the transition between seasonal ice and permafrost is real, the implications of which are discussed below.

\subsection{Influence of Annual Temperature Variations}

[29] Increasing $\mathrm{Ta}$ affects the rate at which the surface temperature passes through the -3 to $-8^{\circ} \mathrm{C}$ temperature window and also the magnitude of changes in temperature at depth. For sites with a positive MAT, an increase in annual temperature variation causes the maximum depth of segregation ice growth and the depth of maximum cracking intensity to deepen (Figure 6a). The change in the maximum depth of segregation ice growth reflects variations in temperature at depth within the rock. For example, a change from an annual temperature variation at the rock surface from $4^{\circ} \mathrm{C}$ to $20^{\circ} \mathrm{C}$ represents a change from $0.4^{\circ} \mathrm{C}$ to $2^{\circ} \mathrm{C}$ at $7 \mathrm{~m}$ depth. Changing the amplitude of the temperature variation increases the depth at which the rock crosses into the frost cracking window. Also, an increase in the amplitude of the annual temperature variation results in shallower levels of the rock spending more time below $-8^{\circ} \mathrm{C}$, where ice growth does not occur.

[30] Negative MATs produce a more complicated cracking intensity-depth profile than positive MATs (Figure 6b). Increasing Ta causes a decrease in the minimum depth of segregation ice growth, as well as a flattening and widening of the zone of peak cracking intensity (Figure 6b). Shallowing of the minimum ice growth depth occurs because the first icy day occurs earlier in the year (earlier in spring) when surface temperature gradients are steeper and the $-3^{\circ} \mathrm{C}$ isotherm is shallower. The flattening and broadening of the peak in maximum cracking intensity reflects increased penetration of the surface temperature perturbation into the rock mass. As a result, more days are spent within the frost cracking window at depth (usually between 400 and $600 \mathrm{~cm}$ ) but temperature gradients are lower at that depth, leading to a flat profile (c.f. Figures 5 and 6).

\subsection{Summary Effects of Ta and MAT}

[31] To apply our model to natural systems, we have summarized our depth profiles by using simple measures of the depth, variability, and intensity of frost-cracking conditions. We have chosen four quantities to describe our model results; mean depth of ice growth, maximum depth of ice growth, standard deviation of ice growth depth, and maximum cracking intensity. These quantities best describe the range of variability in depth and intensity of segregation ice growth given the differences in the depth profiles of cracking intensity between positive and negative MAT. Profiles for positive MAT sites extend from the surface with a sharp peak in cracking intensity at or close to the surface. In contrast, negative MAT sites have a broad peak in cracking intensity at depth within the rock that does not reach the surface. The difference in shape of these distributions suggests that while much of the variability in ice growth depth can be represented by a maximum for positive MATs, the mean and standard deviation are more appropriate for negative MAT sites.

[32] For positive MAT sites, maximum ice growth depth decreases systematically with increasing temperature (Figure 7a). Maximum ice growth depth is less useful for characterizing segregation ice depth for negative MATs 

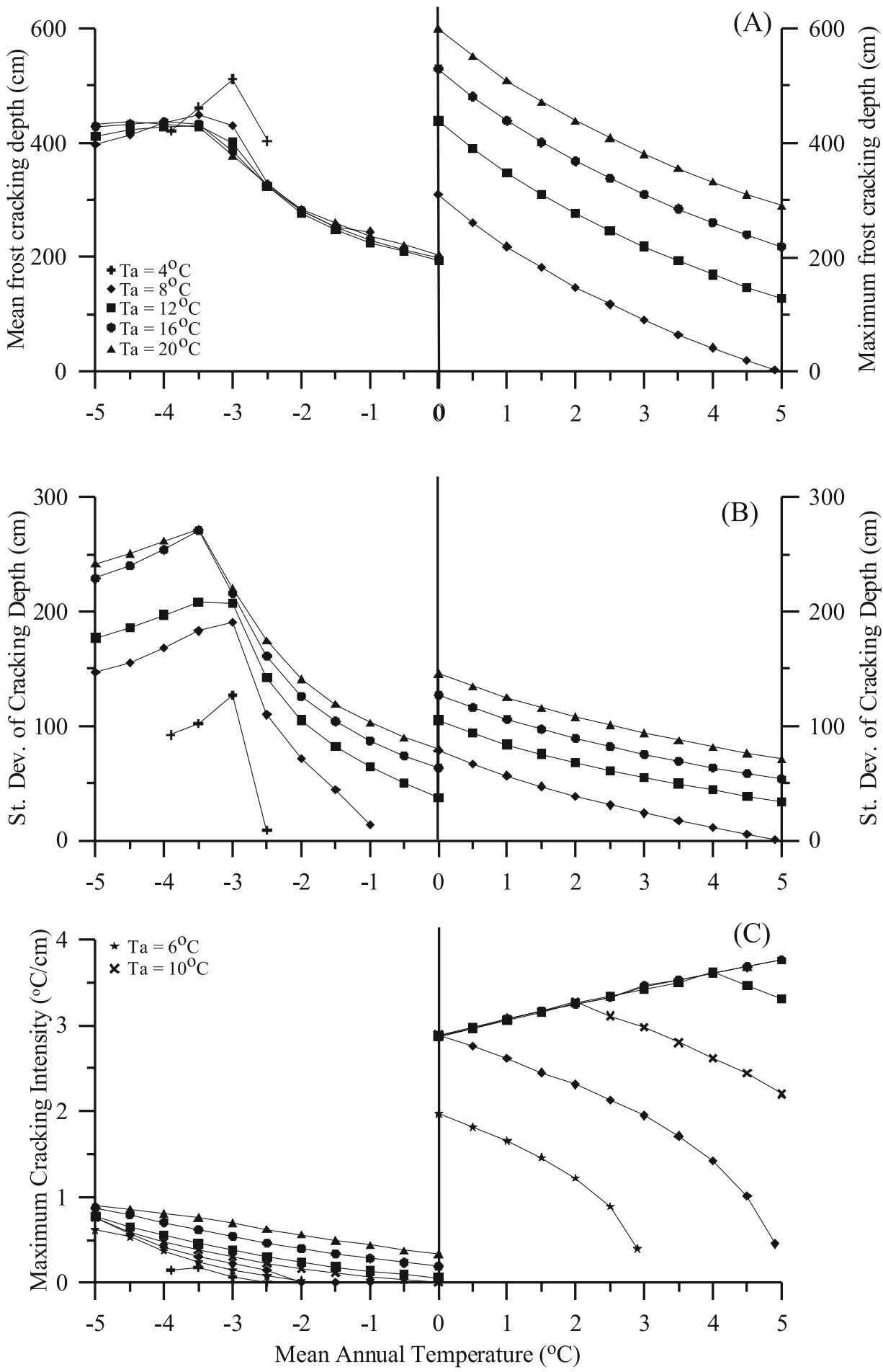

Figure 7. Summary of the effects of changes in MAT and Ta depth and intensity of frost cracking. (a) Changes in the maximum (for positive MATs) and mean (for negative MATs) cracking depth with MAT and Ta. Positive MATs show a progressive increase in the maximum depth of frost cracking with decreasing MAT and increasing Ta. Negative MATs show an increasing mean cracking depth with decreasing MAT but relative uniformity with variations in Ta. Mean cracking depth was calculated as the mean of the distribution of cracking intensity as a function of depth. (b) Standard deviation of cracking depth as a function of MAT. The panel shows that the width of the distribution increases with increasing Ta for both negative and positive MATs. (c) Maximum cracking intensity as a function of MAT and Ta. The peak cracking intensity is an order of magnitude greater for positive MAT. 
because segregation ice growth can occur at very low rates deep within the rock mass (up to $1200 \mathrm{~cm}$ depth) (e.g., Figure 6), therefore we use the mean ice growth depth and its standard deviation (Figures $7 \mathrm{a}$ and $7 \mathrm{~b}$ ). Mean ice growth depth for negative MATs is relatively consistent between $250 \mathrm{~cm}$ (for warmer MATs) and $450 \mathrm{~cm}$ (for cooler MATs) (Figure 7a). The largest mean depths occur when $\mathrm{Ta}$ is small, but the mean depth rapidly achieves consistency with increasing temperature variation. Consistency in mean ice growth depth contrasts with large changes in the standard deviation of depth as a function of Ta and MAT (Figure 7b). The standard deviation increases to reflect the flattening of the distribution with increasing Ta (Figure 6b).

[33] An order of magnitude difference in cracking intensity exists between the positive and negative MAT regions (Figure 7c). Rock masses with positive MATs experience a maximum cracking intensity that increases from 3 to $4^{\circ} \mathrm{C} /$ $\mathrm{cm}$ between 0.001 and $5^{\circ} \mathrm{C}$ at $\mathrm{Ta}$ above $12^{\circ} \mathrm{C}$. The finite number of days a rock mass can spend within the -3 to $-8^{\circ} \mathrm{C}$ temperature window regulates the maximum cumulative gradient that can be achieved for a given MAT. Higher MATs experience greater maximum cumulative temperature gradients because they cross into the temperature window during the late autumn and winter, close to the minimum value in the annual temperature curve, when daily temperature changes at the surface are small. A useful illustration of how maximum cracking intensity is related to days spent in the cracking window is shown for Ta values below $12^{\circ} \mathrm{C}$. At low Ta, the pattern of increasing maximum cracking intensity with MAT is reversed because higherMAT areas spend very few days in the temperature window. For example, at a Ta of $6^{\circ} \mathrm{C}$ and a MAT of $0.01^{\circ} \mathrm{C}$, a rock mass spends 122 days in the temperature window, whereas regions with MAT of $2.5^{\circ} \mathrm{C}$ experience only 48 days. The maximum cracking intensity calculation is less meaningful for negative MATs as the distribution of cracking intensity flattens with higher Ta. Importantly, the maximum cracking intensity is considerably smaller for negative MAT.

\section{Discussion}

[34] Our model results predict the depth of potential segregation ice growth in a rock mass on the basis of mean annual temperature and annual temperature variation. This model can be coupled with relevant geotechnical data such as rock fracture spacing and rock strength measurements (such as Rock Quality Designation [Deere and Deere, 1988] and Rock Mass Strength [Selby, 1980]) to predict patterns of ice-driven rockfall erosion across mountain ranges. Advantages of this model are its simplicity and that it uses readily available data.

\subsection{Segregation Ice Growth and Rock Fracture}

[35] For segregation ice growth to be an important geomorphic agent it must be efficient at fracturing bedrock. Rocks typically contain fractures formed by a number of topographic, depositional and tectonic processes, which commonly provides most of the primary porosity and permeability of a rock mass [Selby, 1982]. Both porosity and permeability are important parameters in segregation ice growth as pores in rock provide sites for the nucleation and growth of ice crystals, and permeability controls the efficiency with which water can be drawn from warmer parts of the rock. The model results described above show that segregation ice growth is most efficient above $300 \mathrm{~cm}$ for positive MATs and above $700 \mathrm{~cm}$ for negative mean annual temperatures. These results suggest that rocks with significant porosity and permeability above these depths may be subject to weathering via the segregation ice mechanism.

[36] The shear strength and orientation of fractures controls the overall strength of rocks [Deere and Deere, 1988; Selby, 1982]. The shear strength of a fracture is controlled by its roughness, cohesion from intermolecular bonding and the amount of clay minerals present within the joint. Segregation ice growth reduces the shear strength of fractures by creating a tensional stress, which can break intermolecular bonds, dilate the rock mass, and reduce the effectiveness of joint roughness. As such, rock fractures are relevant to mountain erosion via frost processes because they serve as the loci of ice growth as well as provide planes of weakness over which failure can occur. In porous systems, particularly soils, heaving pressures associated with water migration may exceed $20 \mathrm{MPa}$, ample pressure to cause rock fracture [Walder and Hallet, 1985]. Walder and Hallet [1985] coupled a model of segregation ice growth with a rock fracture model of stress in "pennyshaped" cracks, and showed that new fractures propagate up to $10^{-7} \mathrm{~m} / \mathrm{s}$ at an ice pressure of 10-12 MPa. Experiments of frost cracking in unfractured sandstones confirmed these theoretical predictions [Hallet et al., 1991].

[37] We suggest fracture spacing may provide a simple, easily measured proxy for determining how susceptible a rock mass is to erosion by segregation ice growth. Rock fractures that intersect our predicted zone of segregation ice growth are therefore susceptible to frost cracking. We suggest that coupling our model with field measurements of the fracture spacing may provide a first-order understanding of likely sites of rockfall erosion.

\subsection{Comparison to Previous Studies}

[38] In an attempt to provide some initial constraints on our simple model, we compare our modeled results with three different data sets from the literature.

\subsubsection{Timing of Rockfall Erosion}

[39] A test of the applicability of our model is to compare our estimates of the timing of segregation ice growth with the timing of rockfall erosion. Our model predicts that rockfalls are more likely in the autumn and early winter for locations with a positive MAT and in the spring and summer for locations with a negative MAT (Figures 2 and 3). Two rockfall inventories in the Canadian Rockies counted the number of rockfall events in a small alpine drainage basin and showed that rockfall frequency peaked in the spring, with a smaller peak in the autumn [Gardner, 1983; Luckman, 1976]. While no accurate temperature data exists for the sites considered, interpolation of MAT from nearby temperature recordings coupled with a lapse rate of $0.6^{\circ} \mathrm{C} /$ $100 \mathrm{~m}$ show that both sites have a MAT of less than $0^{\circ} \mathrm{C}$. A study of the volume of rockfall debris falling onto a snow covered talus slope in a cirque in the Japanese Alps (MAT of $\sim-2^{\circ} \mathrm{C}$ ), showed a similar pattern of rockfall frequency, with a large peak in the spring, and a smaller peak in the autumn [Matsuoka and Sakai, 1999]. These field obser- 

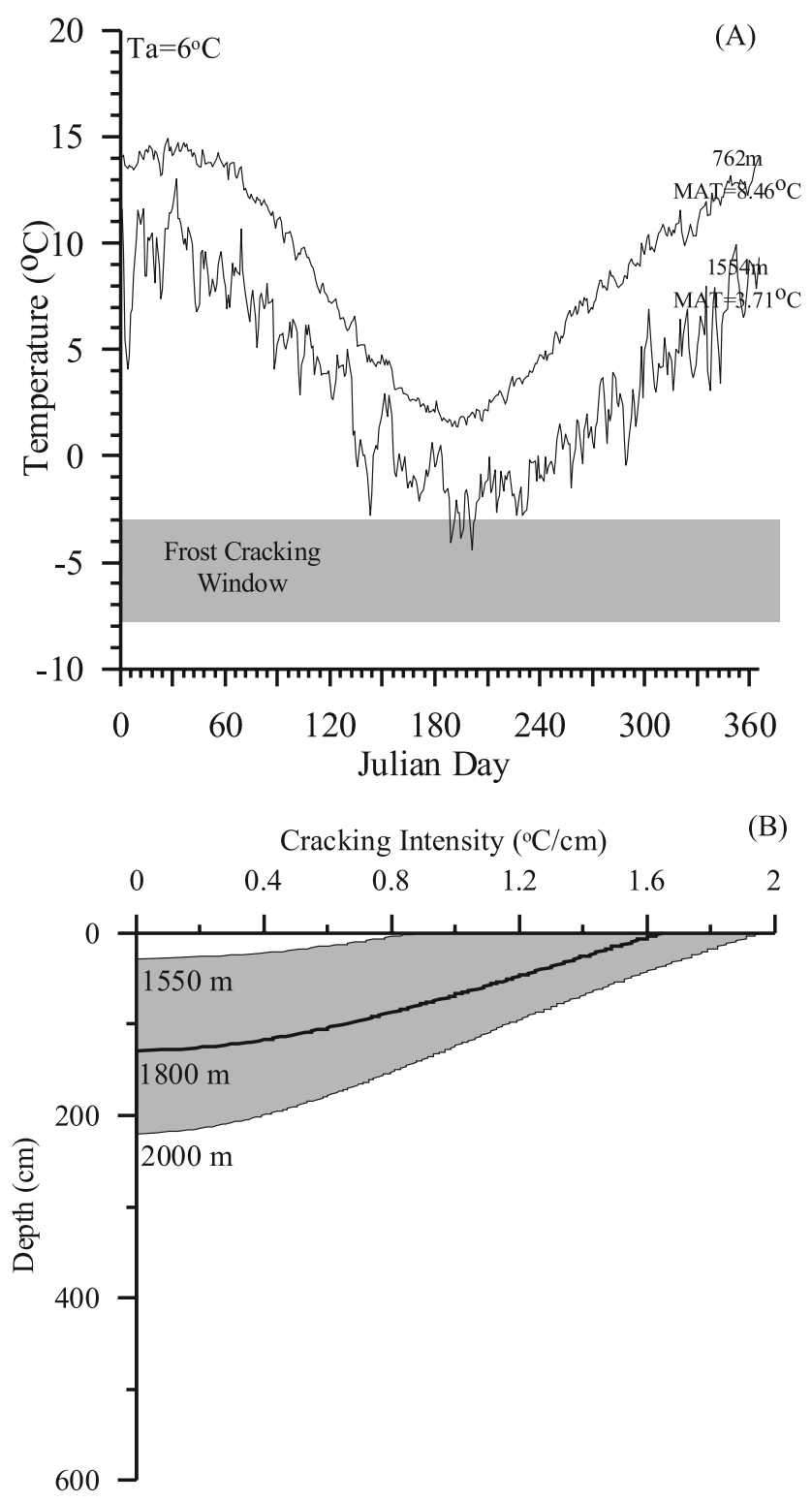

Figure 8. Yearly atmospheric temperature variation in the Southern Alps (a) and the predicted depth of segregation ice growth determined by our model (b). Figure $8 \mathrm{a}$ shows annual air temperatures from the Cragieburn Range $(1554 \mathrm{~m})$ and Mount Cook $(762 \mathrm{~m})$. Figure $8 \mathrm{~b}$ gives the depth of segregation ice growth at an elevation of $1800 \pm$ $250 \mathrm{~m}$ in the Southern Alps (MAT $=1 \pm 1.5^{\circ} \mathrm{C}, \mathrm{Ta}=6^{\circ} \mathrm{C}$ ).

vations appear to support a peak in rockfall activity during spring thawing periods for rocks found in areas with a MAT $<0^{\circ} \mathrm{C}$, however the also show a peak in activity in the autumn, which is not consistent with our model. A study of the amount of rockfall debris collected over the between December 1983 and April 1984 in the Niagara Escarpment, Canada (MAT of $6^{\circ} \mathrm{C}$ ), showed a peak in rockfall activity in the February and March [Fahey and Lefebure, 1988]. The peak in these data is also not entirely consistent with predictions made in our model (we would predict rockfall earlier in the winter). The discrepancies between our model predictions and the timing of rockfall may reflect the influence of diurnal temperature fluctuations, which will particularly affect densely fractured rock masses.

\subsubsection{Southern Alps, New Zealand}

[40] Hales and Roering [2005] attempted to understand the rate and distribution of rockfall erosion in the Southern Alps by mapping rockfall deposits (scree slopes) in a transect across the orogen. Scree slopes in the Southern Alps are well preserved by the geometry of the glacial valleys in which they are deposited and thus accurately preserve a record of rockfall erosion. The authors showed that the fractional area of scree-covered slopes peaked in the eastern part of the range, which precluded earthquakes, topographic unloading, and rock type from being the dominant rockfall generation mechanism. Instead, scree slopes were found within a narrow elevation range with a mean of $\sim 1500 \mathrm{~m}$ and a standard deviation of $\sim 250 \mathrm{~m}$, coincident with elevations immediately below the frost cracking window.

[41] We used their data set to test our model by comparing the predicted elevations of maximum intensity segregation ice growth with the elevations of observed rockfall erosion. We calculated the annual temperature variation and MAT as a function of elevation and using 7 climate stations, found between 42.5 and $44^{\circ} \mathrm{S}$ latitude and covering an elevation range of 762 to $1554 \mathrm{~m}$ over 20 to 99 years (K. McGill, Database of daily temperature data for the central Southern Alps, personal communication, 2003). All climate stations showed a narrow annual temperature variation of $12^{\circ} \mathrm{C}\left(\mathrm{Ta}=6^{\circ} \mathrm{C}\right)$ and MATs that varied between $\sim 8.5$ and $3.7^{\circ} \mathrm{C}$, with a lapse rate of $0.6^{\circ} \mathrm{C} / 100 \mathrm{~m}$ (Figure $8 \mathrm{a}$ ).

[42] Initial model runs at an elevation of $1550 \pm 250 \mathrm{~m}$ (MAT $=2.5 \pm 1.5^{\circ} \mathrm{C}, \mathrm{Ta}=6^{\circ} \mathrm{C}$ ) showed that cracking is likely to occur, but these elevations were not coincident with modeled maximum cracking intensities. Scree slopes form as rockfall deposits at the base of rock headwalls [Rapp, 1960], and so do not directly coincide with the location of maximum frost action. Scree slopes in the Southern Alps are typically $200-300 \mathrm{~m}$ in length [Hales and Roering, 2005], suggesting that the location of rock headwalls is a few hundred meters above the average scree slope elevation. To account for this observation, we recalculated our model with a mean elevation of $1800 \pm 250 \mathrm{~m}$ (MAT $=1 \pm 1.5^{\circ} \mathrm{C}, \mathrm{Ta}=6^{\circ} \mathrm{C}$ ) (Figure $8 \mathrm{~b}$ ). In this case, the maximum predicted segregation ice depths range from $27 \mathrm{~cm}$ at an elevation of $1550 \mathrm{~m}$ to $219 \mathrm{~cm}$ at an elevation of $2000 \mathrm{~m}$. The intensity depth profiles show that the peak cracking intensity is felt at the surface and peak temperature gradients range from 1.95 to $0.8^{\circ} \mathrm{C} / \mathrm{cm}$ (Figure $8 \mathrm{~b}$ ). As such, the mean rock headwall elevation $(1800 \mathrm{~m})$ coincided with the most intense cracking predicted by our model (between 2 and $0^{\circ} \mathrm{C}$ ). We predict elevations above $2000 \mathrm{~m}$ (or below the $0^{\circ} \mathrm{C}$ isotherm) to have considerably lower frost cracking intensities (coincident with the "high and frozen" condition of Hales and Roering [2005]), while elevations below $1600 \mathrm{~m}$ will have low frost cracking intensities.

[43] We also compared the depth penetration of segregation ice growth with measures of rock strength and fracture spacing in the Southern Alps. The pervasive Torlesse Supergroup rocks (sandstones and argillites) are weak and highly fractured, with a mean joint spacing $<20 \mathrm{~cm}$ [Augustinus, 1995; MacKinnon, 1983]. Our model results predict a maximum cracking depth of $27-219 \mathrm{~cm}$ and there 

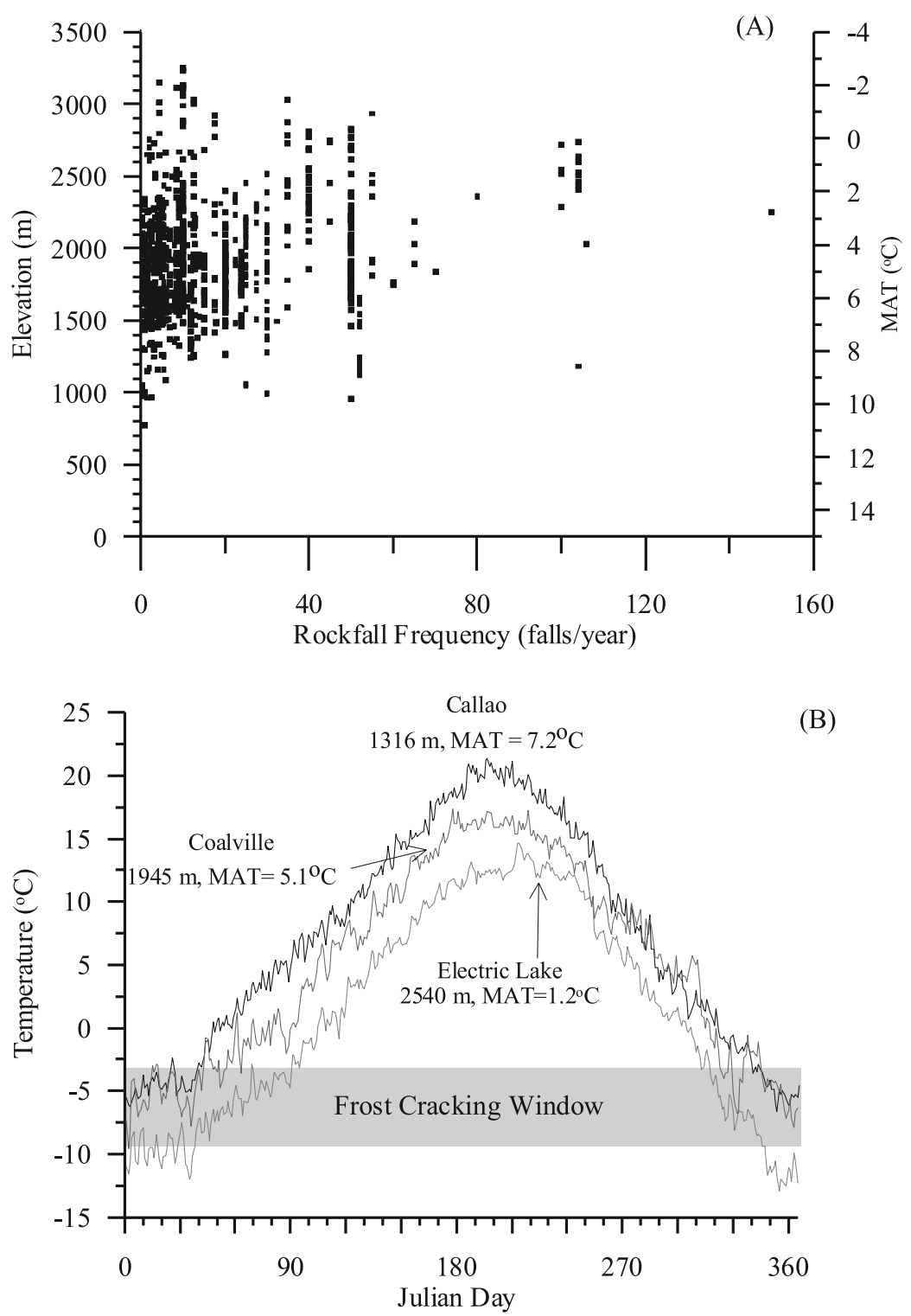

Figure 9. Elevation and frequency of rockfall events on roads in Utah [Pack and Boie, 2002]. (a) There is a distinctive peak in rockfall frequency above $2000 \mathrm{~m}$ elevation reflecting the first influence of segregation ice growth. (b) Annual temperature curves for three temperature stations in Utah (Callao, Coalville, and Electric Lake) that were used to create predictions of frost cracking depths used for comparison with the rockfall frequency data.

is a high likelihood of fractures intersecting the zone of segregation ice growth.

\subsubsection{Utah Rockfall Inventory}

[44] Lastly, we compared the elevation of predicted maximum segregation ice growth to a rockfall inventory data set collected by the Utah Department of Transportation [Pack and Boie, 2002]. This data set was gathered to understand road hazards from rockfall. Rockfall frequency (expressed as rockfalls/year) and block size data were combined with measures of rockfall susceptibility (e.g., the presence of geotechnical structures that reduce amount of road failures) to create a rockfall hazard rating [Pack and Boie, 2002]. We focused on the relationship between rockfall frequency and elevation. Rockfall frequency was calculated by recording of the number of times a road crew had to collect debris from a section of road. This provides a sample of rock headwalls adjacent to roads. Elevations were measured at the road with a median hillslope length of $156 \mathrm{~m}$ (with and interquartile range of 96-283 m). Rockfall frequency varies between 0 and 160 falls/year, with a peak in rockfall intensity at road elevations between 2100 and $2800 \mathrm{~m}$ (Figure 9a).

[45] Because this data set was collected across the state of Utah, it covers a range of rock types and climatic regimes. Nonetheless, high mountains are mostly found in the center and northwest sections of the state. We estimated the relationship between elevation and frost penetration adopting a similar technique to that used for the Southern Alps data set, first comparing atmospheric temperature measurements from 10 sites in the northwest and center of the state 
(representative temperature data are presented in Figure 9b) to attain a lapse rate $\left(0.55^{\circ} \mathrm{C} / 100 \mathrm{~m}\right)$. The annual temperature variation at most Utah sites is $\sim 12^{\circ} \mathrm{C}$. The zone of maximum rockfall frequency corresponds to MATs between 3.5 and $-0.5^{\circ} \mathrm{C}$. Model results for these MATs and a Ta of $12^{\circ} \mathrm{C}$ show that $400 \mathrm{~cm}$ is the deepest to which frost action will penetrate and exploit any fractures at shallower depths, given high cracking intensities (Figure 7c). Our model predicts that the most intense cracking occurs at elevations just above the $0^{\circ} \mathrm{C}$ isotherm. The coincidence of the most the highest rockfall frequencies and temperatures close to the $0^{\circ} \mathrm{C}$ isotherm supports a segregation ice origin for the high frequencies. At higher elevations (lower MAT) frost action may penetrate deeper, but the maximum cumulative gradient is approximately an order of magnitude less. The number of roads decreases at elevations above $3000 \mathrm{~m}$ and the small sample size may also be the cause of the drop in rockfall frequencies at these elevations. Given the heterogeneity of rock types and fracture spacing across Utah, the coincidence of the most intense predicted cracking intensity and the highest rockfall frequencies, suggests that the cumulative temperature gradient is important. Unlike the relatively simple New Zealand example, rock type, rock fracture spacing, earthquake frequency, and time since deglaciation, vary considerably across the state. Despite these complications, a first-order relationship appears to exist between temperature and rockfall frequency.

\subsubsection{Implications for Mountain Range Evolution}

[46] We have presented a predictive model for the production of segregation ice in rock masses. For a given mountain range, our model shows that segregation ice weathering may be concentrated in a small elevation range. Having intense weathering concentrated within a small elevation range may affect the relief and absolute elevation for mountains with rock types that are susceptible to segregation ice induced rockfall erosion. For mountains with weak, highly fractured rock masses (e.g., Southern Alps, New Zealand (Figure 1)), peak elevations may be coincident with the frost cracking window. In contrast, areas with strong, coherent rock masses (e.g., Sierra Nevada Mountains, California) may be less susceptible segregation ice weathering, allowing them to maintain higher peak heights. In the Southern Alps, frost-driven rockfall erosion dominates within a narrow elevation band between 1550 and $2000 \mathrm{~m}$ [Hales and Roering, 2005] and less than $0.5 \%$ of the area of the range is greater than $2000 \mathrm{~m}$. Conversely, the peak elevations of the Sierra Nevada (Mt. Whitney, $4421 \mathrm{~m}$ ) are approximately $1000 \mathrm{~m}$ higher than the $0.001^{\circ} \mathrm{C}$ isotherm, where frost cracking is most efficient. Mt Whitney granodiorite has a large fracture spacing [Stock et al., 2006] and is likely less affected by segregation ice weathering.

[47] An interesting result of our modeling is the dramatic change of behavior across the $0^{\circ} \mathrm{C}$ isotherm, from rapid segregation ice growth close to the surface to a more diffuse ice growth at depth. In our model, this dramatic change in behavior is consistent with a change in water availability in the subsurface (the result of a $0^{\circ} \mathrm{C}$ condition for frost cracking). We suggest that this transition is important in mountainous landscapes as it controls the upper boundary of the frost cracking window described above. At elevations with a MAT above $0^{\circ} \mathrm{C}$, only seasonal ice exists, allowing for water to be drawn readily from both the surface and groundwater. As a result, segregation ice growth is rapid and efficient, generating high rates of frost cracking. At MATs below $0^{\circ} \mathrm{C}$, segregation ice growth rates are an order of magnitude slower, resulting in a high and frozen condition.

[48] Our prediction of an elevation-dependent zone of segregation ice weathering has implications for rockfall erosion on glacial-interglacial timescales. Our model predicts that the elevation range of effective frost processes will be affected by major changes in MAT caused by global warming and cooling events. For high mountains, such as the Himalaya, a warming climate will push the zone of maximum frost cracking up in elevation, potentially affecting the amount of rockfall in high mountain passes. For low, vegetated mountains, such as the Appalachians, a cooling climate may lower the zone of maximum frost cracking erosion, potentially increasing the rate of mechanical weathering. A cooling climate is commensurate with expansion of glaciers and apparently enhanced glacial erosion (called a glacial "buzzsaw"; see Brozovic et al. [1997]). Our model suggests that the elevation of the frost cracking zone is lowered in concert with the expansion of ice masses. Thus global cooling may increase the intensity of segregation ice weathering in glaciated areas and aid in the rapid erosion of mountain peaks (a rockfall "buzzsaw"?).

\section{Conclusions}

[49] The rate of periglacial erosion in mountainous landscapes is a largely unknown quantity, with much debate existing about its role relative to fluvial, glacial and hillslope processes. We have attempted to quantify the role of ice-driven erosion through the use of a simple one dimensional heat flow model. We use this model to predict the depth and intensity of segregation ice growth in rocks using mean annual atmospheric temperature and annual temperature variations. We predict that segregation ice will grow in this model when three simple criteria are met: (1) the rock temperature is between -3 and $-8^{\circ} \mathrm{C}$, (2) one of the boundaries has a temperature above $0^{\circ} \mathrm{C}$, meaning that water is freely available to the system, and (3) the water is drawn from warmer to colder parts of the system. The growth rate of segregation ice in this system is dependent on the temperature gradient. We show that intense segregation ice growth occurs close to the surface of the rock mass for MATs above $0^{\circ} \mathrm{C}$, while at negative MATs segregation ice forms at depths below $50 \mathrm{~cm}$ from the surface. Changes in MAT are manifest by changes in the rate and depth of segregation ice growth, while changes in Ta primarily affect the depth of ice penetration. For areas of seasonal ice growth (temperatures above $0^{\circ} \mathrm{C}$ ), intense frost action occurs close to the surface during the autumn and winter, while weaker segregation ice growth in the presence of permafrost occurs mostly in the spring. We suggest that our predictions of the depth and intensity of segregation ice growth can be related to the fracture spacing of a rock mass to predict the susceptibility of a mountain range to frost action. Examples from the Southern Alps and Utah show that predicted maxima in the intensity of segregation ice growth coincide with maxima in rockfall erosion rates. 
[50] Acknowledgments. Funding for this project was provided by a National Science Foundation grant (EAR-0309975). The authors wish to thank Alex Densmore, Simon Brocklehurst, Bob Anderson, and an anonymous reviewer for careful reviews that improved the manuscript. Discussions with Alan Rempel enhanced the authors' understanding of the concept of chemical potential-driven ice growth.

\section{References}

Anderson, R. S. (1998), Near-surface thermal profiles in alpine bedrock: Implications for the frost weathering of rock, Arct. Alp. Res., 30(4), 362372.

Andre, M.-F. (1997), Holocene rockwall retreat in Svalbard: A triple-rate evolution, Earth Surf. Processes Landforms, 22, 423-440.

Augustinus, P. (1995), Rock mass strength and the stability of some glacial valley slopes, Z. Geomorphol., 39(1), 55-68.

Ballantyne, C. K., and J. D. Eckford (1984), Characteristics and evolution of two relict talus slopes in Scotland, Scott. Geogr. Mag., 100(1), 20-33.

Brozovic, N., D. W. Burbank, and A. Meigs (1997), Climatic limits on landscape development in the northwestern Himalaya, Science, 276 , $571-574$.

Bull, W. B., and P. L. K. Knuepfer (1987), Adjustments by the Charwell River, New Zealand, to uplift and climatic changes, Geomorphology, 1, $15-32$.

Carslaw, H. S., and J. C. Jaeger (1959), Conduction of Heat in Solids, 510 pp., Oxford at the Clarendon Press, London.

Church, M., R. F. Stock, and J. M. Ryder (1979), Contemporary sedimentary environments on Baffin Island, N.W.T., Canada: Debris slope accumulations, Arct. Alp. Res., 11(4), 371-402.

Coutard, J.-P., and B. Francou (1989), Rock temperature measurements in two alpine environments: Implications for frost shattering, Arct. Alp. Res., 21(4), 399-416

Dash, J. G., A. W. Rempel, and J. S. Wettlaufer (2006), The physics of premelted ice and its geophysical consequences, Rev. Mod. Phys., 78(3), $695-741$.

DeCelles, P. G., and P. C. DeCelles (2001), Rates of shortening, propagation, underthrusting, and flexural wave migration in continental orogenic systems, Geology, 29(2), 135-138.

Deere, D. U., and D. W. Deere (1988), The Rock Quality Designation (RQD) index in practice, in Rock Classification Systems for Engineering Purposes, edited by L. Kirkaldie, pp. 91-101, Am. Soc. for Test. and Mater., Philadelphia.

Fahey, B. D., and T. H. Lefebure (1988), The freeze-thaw weathering regime at a section of the Niagara Escarpment on the Bruce Peninsula, Southern Ontario, Canada, Earth Surf. Processes Landforms, 13, 293 304

Frich, P., and E. Brandt (1985), Holocene talus accumulation rates, and their influence on rock glacier growth: A case study from Igpik, Disko, West Greenland, Nor: Geogr. Tidsskrift, 85, 32-45.

Gardner, J. S. (1983), Rockfall frequency and distribution in the Highwood Pass area, Canadian Rocky Mountains, Z. Geomorphol., 27(3), 311-324.

Gilpin, R. R. (1980), A model for the prediction of ice lensing and frost heave in soils, Water Resour. Res., 16, 918-930.

Gold, L. W., and A. H. Lachenbruch (1983), Thermal conditions in permafrost: A review of North American literature, in Permafrost: Fourth International Conference, pp. 3-25, Natl. Acad. Press, Washington, D. C.

Gray, J. T. (1973), Geomorphic effects of avalanches and rock-falls on steep mountain slopes in the central Yukon territory, in Research in Polar and Alpine Geomorphology, edited by B. D. Fahey and R. D. Thompson, pp. 107-117, Geo Abstracts, Norwich.

Gruber, S., M. Hoelzle, and W. Haeberli (2004), Permafrost thaw and destabilization of Alpine rock walls in the hot summer of 2003, Geophys. Res. Lett., 31, L13504, doi:10.1029/2004GL020051.

Hales, T. C., and J. J. Roering (2005), Climate-controlled variations in scree production, Southern Alps, New Zealand, Geology, 33(9), 701-704.

Hall, K., B. S. Lindgren, and P. Jackson (2005), Rock albedo and monitoring of thermal conditions in respect of weathering: Some expected and some unexpected results, Earth Surf. Processes Landforms, 30, 801-811.

Hallet, B., J. Walder, and C. W. Stubbs (1991), Weathering by segregation ice growth in microcracks at sustained sub-zero temperatures: Verification from an experimental study using acoustic emissions, Permafrost Periglacial Processes, 2, 283-300.

Hallet, B., L. Hunter, and J. Bogen (1996), Rates of erosion and sediment evacuation by glaciers: A review of field data and their implications, Global Planet. Change, 12, 213-255.

Harris, S. A., and D. E. Pederson (1998), Thermal regimes beneath coarse blocky materials, Permafrost Periglacial Proc., 9, 107-120.

Henry, K. S. (2000), A review of the thermodynamics of frost heave, Tech. Rep. ERDC/CRREL TR-00-16, 19 pp., Cold Reg. Res. and Eng. Lab., U. S. Army Corps of Eng., Washington, D. C.
Hinchliffe, S., and C. K. Ballantyne (1999), Talus accumulation and rockwall retreat, Trotternish, Isle of Skye, Scotland, Scott. Geogr. J., 115(1), $53-70$.

Hiroi, M., T. Mizusaki, T. Tsuneto, A. Hirai, and K. Eguchi (1989), Frostheave phenomena of ${ }^{4} \mathrm{He}$ on porous glasses, Phys. Rev. B, 40(10), $6581-6590$.

Linacre, E., and B. Geerts (1997), Climates and Weather Explained, 432 pp., Routledge, London

Luckman, B. H. (1976), Rockfalls and rockfall inventory data: Some observations from Surprise Valley, Jasper National Park, Canada, Earth Surf. Processes Landforms, 1, 287-298.

MacKinnon, T. C. (1983), Origin of the Torlesse terrane and coeval rocks, South Island, New Zealand, Geol. Soc. Am. Bull., 94, 967-985.

Matsuoka, N. (2001), Direct observation of frost wedging in alpine bedrock, Earth Surf. Processes Landforms, 26, 601-614.

Matsuoka, N., and H. Sakai (1999), Rockfall activity from an alpine cliff during thawing periods, Geomorphology, 28, 309-328.

Montgomery, D. R. (2002), Valley formation by fluvial and glacial erosion, Geology, 30(11), 1047-1050.

Murton, J. B. (1996), Near-surface brecciation of chalk, Isle of Thanet, south-east England: A comparison with ice-rich brecciated bedrocks in Canada and Spitsbergen, Permafrost Periglacial Processes, 7, 153-164.

Murton, J. B., J.-P. Coutard, J.-P. Lautridou, J.-C. Ozouf, D. A. Robinson, and R. B. G. Williams (2001), Physical modelling of bedrock brecciation by ice segregation in permafrost, Permafrost Periglacial Processes, 12, $255-266$.

O'Neill, K., and R. D. Miller (1985), Exploration of a rigid ice model of frost heave, Water Resour. Res., 21(3), 281-296.

Pack, R. T., and K. Boie (2002), Utah Rockfall Hazards Inventory: Phase I, 90 pp., Utah Dept. of Transp., Salt Lake City, Utah.

Pan, B., D. W. Burbank, Y. Wang, G. Wu, J. Li, and Q. Guan (2003), A 900 k.y. record of strath terrace formation during glacial-interglacial transition in northwest China, Geology, 31(11), 957-960.

Rapp, A. (1960), Talus slopes and mountain walls at Tempelfjorden, Spitsbergen: A geomorphological study of the denudation of slopes in an arctic locality, Nor. Polarinst. Skr., 119(4-7), 90-96.

Rempel, A. W., J. S. Wettlaufer, and M. G. Worster (2004), Premelting dynamics in a continuum model of frost heave, J. Fluid Mech., 498, $227-244$.

Sass, O. (2005), Rock moisture measurements: techniques, results, and implications for weathering, Earth Surf. Processes Landforms, 30, $359-374$.

Sass, O., and K. Wollny (2001), Investigations regarding alpine talus slopes using ground-penetrating radar (GPR) in the Bavarian Alps, Germany, Earth Surf. Processes Landforms, 26, 1071-1086.

Selby, M. J. (1980), A rock mass strength classification for geomorphic purposes: With tests from Antarctica and New Zealand, Z. Geomorphol., 24(1), 31-51

Selby, M. J. (1982), Controls on the stability and inclinations of hillslopes formed on hard rock, Earth Surf. Processes Landforms, 7, 449-467.

Selby, M. J. (1993), Hillslope Materials and Processes, 451 pp., Oxford at the Clarendon Press, London.

Stock, G. M., T. A. Ehlers, and K. A. Farley (2006), Where does sediment come from? Quantifying catchment erosion with detrital apatite (U-Th)/ He thermochronometry, Geology, 34(9), 725-728.

Taber, S. (1929), Frost heaving, J. Geol, 37(5), 428-461.

Turcotte, D. L., and G. Schubert (2002), Geodynamics, 456 pp., Cambridge Univ. Press, Cambridge.

Walder, J., and B. Hallet (1985), A theoretical model of the fracture of rock during freezing, Geol. Soc. Am. Bull., 96, 336-346.

Wettlaufer, J. S., and M. G. Worster (1995), Dynamics of premelted films: Frost heave in a capillary, Phys. Rev. E, 51(5), 4679-4689.

Wilen, L. A., and J. G. Dash (1995), Frost heave dynamics at a single crystal interface, Phys. Rev. Lett., 74(25), 5076-5079.

Worster, M. G., and J. S. Wettlaufer (1999), The fluid mechanics of premelted liquid films, in Fluid Dynamics at Interfaces, edited by W. Shyy, pp. 339-351, Cambridge Univ. Press, Cambridge.

Zhang, P., P. Molnar, and W. R. Downs (2001), Increased sedimentation rates and grain sizes 2-4 Myr ago due to the influence of climate change on erosion rates, Nature, 410, 891-897.

Zhu, C. (1996), Rates of periglacial processes in the central Tianshan, China, Permafrost Periglacial Processes, 7, 79-94.

Zhu, D.-M., O. E. Vilches, J. G. Dash, B. Sing, and J. S. Wettlaufer (2000), Frost heave in argon, Phys. Rev. Lett., 85(23), 4908-4911.

T. C. Hales and J. J. Roering, Department of Geological Sciences, 1272 University of Oregon, Eugene, OR 97403-1272, USA. (thales@uoregon. edu; jroering@uoregon.edu) 